\title{
KAJIAN KEBIJAKAN PENINGKATAN PROFESIONALISME GURU DAN DOSEN DI INDONESIA
}

\author{
Idris \\ Program Studi Ilmu Perpustakaan dan Informasi Islam, FUAD, IAIN Palu \\ I_zabir@yahoo.co.id
}

\begin{abstract}
ABSTRAK
Tugas dan tanggung jawab guru dan dosen dituntut untuk mempunyai kemampuan atau kompetensi yang memadai, baik kompetensi personal, kompetensi sosial, kompetensi kepribadian serta sebuah kompetensi professional. Pelaksanaan tugas dan tanggung jawab guru dan dosen tersebut senantiasa perlu dikontrol dan dikembangkan sedemikian rupa sehingga lebih optimal dan relevan dengan kebutuhan yang ada. Di dalam penyelenggaraan pendidikan di lembaga pendidikan tinggi, dosen mempunyai kedudukan yang sangat penting dan strategis dalam kerangka pencapaian tujuan pendidikan yang ditetapkan. Dosen mempunyai otoritas yang cukup besar dalam mengelola pendidikan dan perkuliahan, mulai dari penyusunan rencana perkuliahan, pelaksanaan, dan evaluasi serta tindak lanjutnya. Di samping dalam tugas pada bidang pendidikan dan pembelajaran, dosen juga mempunyai tugas lainnya yaitu melaksanakan kegiatan penelitian, dan kegiatan pengabdian kepada masyarakat
\end{abstract}

Kata Kunci : Profesionalisme, Guru, Dosen

\begin{abstract}
The duties and responsibilities of teachers and lecturers are required to have adequate abilities or competencies, both personal competence, social competence, personal competence and a professional competence. The implementation of duties and responsibilities of teachers and lecturers always needs to be controlled and developed in such a way so that it is more optimal and relevant to existing needs.. In the implementation of education in higher education institutions, lecturers have a very important and strategic position in the framework of achieving the set educational goals. Lecturers have considerable authority in managing education and lectures, starting from the preparation of lecture plans, implementation, evaluation and follow-up. In addition to their duties in the field of education and learning, lecturers also have other tasks, namely carrying out research activities and community service activities
\end{abstract}

Keywords: Professionalism, Teachers, Lecturers

\section{PENDAHULUAN}

Kemajuan ilmu Pengetahuan teknologi (IPTEK) yang terus berkembang pesat seiring perkembangan zaman, memberi tekanan terhadap perilaku umat manusia untuk memenuhi kebutuhan serta berabagi tuntutan hidupnya. Dalam bidang pendidikan, hal ini dapat menjadi perhatian baru untuk mengubah pameran tenaga kependidikan dan persekolahan sehingga mampu mempersiapkan para pelajar dan orang-orang di masa depan yang dapat bereaksi untuk mendorong ilmu pengetahuan dan inovasi, seperti kebutuhan dan permintaan masyarakat.

Siswa dan genenasi milenial Indonesia saat ini merupakan sumber daya manusia masa depan yang hidup pada era global. Globalisasi dapat menekan tingkat kebutuhan untuk menggabungkan model 
atau siklus dalam pembelajaran dalam jalur yang inovatif, menyenangkan, dan inovatif untuk pencapaian pengetahuan, kecukupan, keseriusan, dan atribut publik di seluruh dunia. Dengan begitu meningkatkan wawasan, dalam menghargai ilmu dan inovasi, kemampuan, dan karakter masyarakat untuk mengangkat status bangsa.

Kemajuan masyarakat dalam berbagai bidang pendidikan merupakan dorongan untuk mendidik kehidupan bangsa dan meningkatkan sifat usia muda individu Indonesia yang berdedikasi, bertaqwa, dan beretika luhur, yang mampu menguasai ilmu pengetahuan, inovasi, dan ketrampilan dalam memahami. masyarakat umum sesuai dengan keyakinan yang berkembang, berakal sehat, sejahtera, dan bermasyarakat yang berlandaskan dari dasar Pancasila dan Undang-Undang Dasar Negara Republik Indonesia Tahun 1945.

Untuk menjamin perluasan serta pemerataan tujuan yang berbeda, peningkatan kualitas ketepatan, seperti dalam administrasi besar yang dikoordinasikan pada tanggung jawab, dipercaya bahwa sekolah yang dapat menghadapi kesulitan sesuai dengan permintaan perubahan lingkungan, kehidupan publik dan dunia harus terlibat dan meningkatkan sifat pendidik dan dosen yang semuanya diatur, terkoordinasi, dan ekonomis sehingga pendidik dan dosen memiliki kapasitas, pekerjaan dan posisi yang sangat penting dalam kemajuan publik di bidang pendidikan.

Guru adalah instruktur pembelajaran profesional yang kewajibannya mencakup pengajaran, pengarahan, pengendalian, serta mengoordinasikan, mempersiapkan, mensurvei, dan menilai siswa di tingkat pendidikan anak usia dini melalui jalur pendidikan formal, pendidikan dasar, dan pendidikan menengah. Dosen adalah instruktur pembelajaran yang juga peneliti dengan tugas mendasar untuk mengubah, menciptakan dan menyebarkan berbagai ilmu, inovasi, dan ekspresi melalui pelatihan, eksplorasi, dan administrasi ke seluruh masyarakat.

\section{PEMBAHASAN}

\section{A. Profesi dan Profesionalisme Guru}

Guru yaitu panutan sebagai seorang pendidik yang sesunguhnya. UndangUndang RI Nomor 14 Tahun 2005 Tentang Guru dan Dosen Pada pasal 1 disebutkan yaitu:

Guru adalah pendidik profesional dengan tugas utama mendidik, mengajar, membimbing, mengarahkan, melatih, menilai dan mengevaluasi peserta didik pada pendidikan anak usia dini jalur pendidikan formal, pendidikan dasar dan pendidikan menengah. Profesi sebagai seorang guru harus dipandang dari beberapa sisi kehidupan secara luas.

Hamalik mengungkapkan bahwa pendidikan memerlukan:

1. Pekerjaan dalam hal pendidikan harus dilihat dalam pengaturan kemajuan yang berbeda secara umum, yang diharapkan dapat membentuk individu sesuai dengan standar negara.

2. Konsekuensi pengajaran mungkin tidak terlihat atau dirasakan dalam jangka waktu yang singkat, namun dapat terlihat cukup lama, bahkan mungkin setelah melewati satu atau beberapa usia.

3. Sekolah adalah lembaga yang profesional yang diharapkan mampu membentuk siswa untuk berkembang, intens, dan mampu tumbuh dewasa baik untuk masyarakat maupun diri mereka sendiri.

4. Sesuai dengan sifat dan aturan profesi yang digambarkan sebelumnya, pekerjaan pendidik jelas harus dilakukan oleh individu yang merupakan pendidik.

5. Hakikat setiap pendidik harus memiliki kemampuan yang mahir, kemampuan karakter, dan keterampilan budaya. (Oemar Hamalik, 2002)

Berdasarkan kualitas suatu profesi, setiap pendidik harus memiliki kode etik 
yang dikendalikan sebagai aturan tersirat bagi individu yang bertindak sebagai pelaku profesi dalam hal tertentu, seperti halnya pendidik. Rumusan kode etik Guru Indonesia setelah disempurnakan dalam kongres PGRI XVI tahun 1989 di Jakarta dalam Mulyasa sebagai berikut:

1. Pendidik diberikan kemampuan untuk mengontrol siswa untuk membingkai manusia Indonesia seutuhnya yang berjiwa Pancasila

2. Pendidik mempunyai dan melaksanakan kejujuran profesional;

3. Pendidik berusaha mendapatkan data tentang siswa sebagai bahan untuk arahan dan pelatihan memimpin;

4. Pendidik membuat iklim paling ideal yang mendukung pencapaian ukuran mendidik dan pembelajaran;

5. Pendidik menjaga hubungan baik dengan wali murid dan masyarakat yang meliputi untuk menumbuhkan kerja sama dan perasaan tugas bersama terkait pelatihan;

6. Pendidik secara eksklusif dan bersamasama menciptakan dan meningkatkan kualitas dan kebanggaan panggilan mereka;

7. Pendidik menjaga hubungan baik dengan rekan seprofesi disertai jiwa kekeluargaan, dan solidaritas sosial

8. Pendidik saling menjaga dan meningkatkan kualitas PGRI sebagai sarana pertempuran dan administrasi;

9. Pendidik melakukan semua pendekatan administrasi di bidang pendidikan. (E Mulyasa, 2008)

Pada Undang-Undang Nomor 14 Tahun 2005 tentang Guru dan Dosen Pasal 1 ayat (1) menyebutkan guru:

Pendidik profesional dengan tugas utama mendidik, mengajar, membimbing, mengarahkan, melatih, menilai, dan mengevaluasi peserta didik pada pendidikan anak usia dini jalur pendidikan formal, pendidikan dasar dan pendidikan menengah.

\section{B. Standar Kompetensi Guru Profesional}

Seperti halnya pendidik yang harus memiliki kapabilitas, seorang pendidik yang mengenyam pendidikan di organisasi pendidikan formal,mulai dari yang sekolah dan madrasah paling dasar, sampai tingkat menengah dibutuhkan kompetensi berupa kumpulan pengetahuan dan bakat, dan perilaku yang harus dimiliki, dihayati, dikuasai, dan diaktualisasikan yang terdapat dalam Peraturan Pemerintah Nomor 74 Tahun 2008 tentang Guru Pasal $10)$.

Menurut Johnson dalam Sagala yang dijelaskan bahwa "Keterampilan adalah perilaku yang wajar untuk mencapai tujuan yang diperlukan sesuai kondisi normal. Definisi ini mengisyaratkan bahwa keterampilan merupakan kebutuhan mutlak yang dimiliki untuk suatu profesi". Rumusan kompetensi menurut Sagala tersebut mengandung tiga bagian yaitu:

1. Kapasitas, pengetahuan, tentang kemampuan, mentalitas, kualitas, mendapatkan, pujian dan keinginan yang menggambarkan seseorang dalam menyelesaikan kewajibannya.

2. Kualitas dan karakter tingkah laku yang digambarkan dalam sudut pandang utama terlihat jelas dalam aktivitas, perilaku, dan pelaksanaannya.

3. Hasil presentasi dapat memenuhi standar pedoman kualitas tertentu. Perspektif ini mengacu pada kesesuaian yang sesuai hasil (output atau outcome) dari unjuk kerja.

Secara keseluruhan, kompetensi adalah perpaduan dari dominasi pengetahuan, kemampuan, nilai dan sikap yang dapat tercermin dalam kecenderungan dari cara pandang atau tindakan untuk melakukan profesi atau kewajiban. Jadi kompetensi adalah sekumpulan pengetahuan, bakat, dan praktik yang harus dimiliki, dijalankan, dan dimiliki oleh pendidik untuk menyelesaikan kewajiban sebagai pendidik profesional.

Berdasarkan UU No. 14 tahun 2005 tentang Guru dan Dosen Pasal 8 menyatakan bahwa: 
Seorang Guru wajib memiliki kualifikasi akademik, kompetensi, sertifikat pendidik, sehat jasmani dan rohani, serta memiliki kemampuan untuk mewujudkan tujuan pendidikan nasional.

Selanjutnya Pasal 10 ayat (1) menyatakan:

Kompetensi guru sebagaimana yang dimaksud dalam Pasal 8 meliputi kompetensi pedagogik, kompetensi kepribadian, kompetensi sosial, dan kompetensi profesional yang diperoleh melalui pendidikan profesi. (Syaiful Sagala, 2009)

\section{Kebijakan Pengembangan Profesionalisme Bagi Guru}

Menurut Edwards dan Sharkansky dalam Wahab (2011) strategi publik adalah "hal yang dikatakan dan dilaksanakan oleh pemerintah dan apa yang dilakukan atau tidak dilakukan adalah tujuan atau tujuan program untuk penggunaan tujuan dan peraturan yang ada.. Selanjutnya Anderson dalam Islamy (2002) menganggap kebijakan publik sebagai hasil dari kesepakatan badan negara dalam hal ini pejabat pemerintah. Menurut R.S Parker dalam Wahab (2011) kebijakan publik adalah tujuan tertentu, atau pengaturan standar tertentu, atau kegiatan yang dilakukan oleh administrasi pada waktu tertentu sesuai dengan subjek atau karena keadaan darurat.

Dalam hal ini Kebijakan publik memiliki tingkatan, Nugroho (2006) menegaskan bahwa secara sederhana susunan atau tingkatan kebijakan publik di Indonesia dapat dibagi menjadi tiga, yakni:

1. Kebijakan publik yang bersifat umum atau makro.

2. Kebijakan Publik yang bersifat (meso) menengah.

3. Kebijakan Publik yang bersifat mikro.

Dari penggambaran urutan atau tingkat pendekatan di atas, jelas strategi terbuka yang ada sebagai peraturan perundang-undangan atau pedoman lokal merupakan pengaturan publik yang sifatnya kunci namun belum terealisasi, karena memang membutuhkan deduksi strategi lebih lanjut atau informatif. pengaturan publik atau apa yang biasa disebut. sebagai pedoman pelaksanaan atau petunjuk penggunaan.

Pengembangan dan peningkatan kemampuan pendidik yang memiliki sertifikat pendidik dilakukan untuk menjamin bahwa keahlian keahliannya sesuai dengan kemajuan ilmu pengetahuan, inovasi, ekspresi, dan budaya dan atau olahraga. Pergantian peristiwa dan peningkatan kemampuan dibantu melalui pengaturan arahan yang konstan dan peningkatan ahli pendidik yang terkait dengan perolehan angka kredit jabatan fungsional.

Penegembangan kemampuan pendidik dilaksanakan degan berbagai cara salah satunya adalah dengan pendidikan dan pelathan dan bukan Diklat seperti:

1. Inhouse training (IHT). Pelatihan IHT yang dilakukan di dalam KKG atau MGMP, sekolah dan berbagai tempat yang telah ditetapkan memiliki opsi untuk mengkoordinasikan persiapan. Teknik pelatihan melalui IHT dilaksanakan dengan alasan bahwa porsi kapasitas untuk meningkatkan kemampuan dan karir pendidik tidak perlu dilakukan dari jarak jauh, namun harus dimungkinkan oleh pendidik yang memiliki keterampilan kepada pendidik lain yang tidak memiliki kemampuan. Dengan teknik atau sistem ini diharapakan dapat mengifisienkan waktu dan biaya.

2. Program magang. Program magang adalah salah satu bentuk persiapan yang dilakukan oleh organisasi / bisnis yang berlaku untuk meningkatkan kemampuan pengajar. Program magang ini pada prinsipnya diusulkan untuk pendidik profesional dan harus dimungkinkan selama jangka waktu tertentu, misalnya, posisi sementara dalam bisnis mobil dan semacamnya. Program magang dipilih sebagai pilihan berbeda dengan pengarahan mengingat fakta bahwa kemampuan tertentu, 
terutama untuk guru profesional, membutuhkan pengalaman yang murni.

3. Kemitraan sekolah. Persiapan yang dibantu melalui asosiasi sekolah dapat dilakukan dengan kerjasama antara yayasan pemerintah atau swasta dalam kemampuan tertentu. Penggunaannya juga harus dimungkinkan di sekolah atau di sekolah kaki tangan. Mengajar melalui kaki tangan atau relasi sekolah diperlukan karena sebagian dari keunikan atau kualitas kaki tangan dapat dimanfaatkan oleh pendidik yang berpartisipasi dalam persiapan untuk meningkatkan kebugaran ahli mereka.

4. Belajar jarak jauh. Persiapan dibantu melalui pembelajaran pemisahan dapat diselesaikan tanpa memperkenalkan guru atau pembimbing dan siswa di satu tempat tertentu, namun dengan kerangka kerja persiapan melalui web dan semacamnya. Pengarahan melalui pembelajaran pemisahan dilengkapi dengan pemikiran bahwa tidak semua pendidik, terutama yang berada di zona yang jauh, dapat pergi mempersiapkan diri di tempat-tempat persiapan yang telah ditentukan, misalnya di daerah atau ibukota negara.

5. Pelatihan berjenjang dan pelatihan khusus. Persiapan semacam ini diselesaikan oleh P4TK dan / atau LPMP dan instansi lain yang sangat disetujui, di mana program persiapanya diatur secara bertahap, mulai dari tingkat esensial, tengah jalan, maju dan signifikan. Tingkat persiapan ini didasarkan pada keadilan dan kesukaran dan jenis kompetensi. Persiapan yang tidak umum (spesialisasi) diberikan bergantung pada persyaratan khusus atau karena peningkatan baru dalam informasi tertentu.

6. Kursus singkat di LPTK atau lembaga pendidikan lainnya Kursus singkat yang dipimpin oleh LPTK atau lembaga instruktif yang berbeda diharapkan dapat mempersiapkan kemampuan instruktur dalam beberapa kapasitas, misalnya memimpin penelitian kegiatan wali kelas, memesan makalah logis, menyusun, melaksanakan dan menilai pembelajaran, dan lain-lain.

7. Pembinaan internal oleh sekolah. Pelatihan internal ini dapat dilakukan oleh kepala dan pendidik yang memiliki posisi untuk mengelola, melalui pertemuan otentik, poros menunjukkan usaha, memberikan tugas ekstra ke dalam, percakapan dengan teman sebaya dan s e m a c a m y a .

8. Pendidikan lanjut. Peningkatan profesi pengajaran melalui pendidikan tambahan juga merupakan pilihan untuk kemajuan profesi pendidik di kemudian hari. Partisipasi pendidik dapat dilakukan dengan memberikan tugas belajar, baik di dalam maupun di luar negeri, bagi pendidik yang berhasil. Penggunaan pendidikan lanjutan ini akan menciptakan instruktur panduan yang dapat membantu pendidik yang berbeda dalam upaya kemajuan ahli mereka. (Kemdikbud, 2012)

Selain itu, kegiatan lainnya yang dapat dilaksanakan terdapat kegiatan dalam peningkatan kompetensi guru yaitu:

1. Diskusi masalah pendidikan.

Diskusi ini diselenggarakan dengan secara berkala Mata pelajaran mana yang sesuai dengan masalah yang dialami di sekolah. Melalui percakapan sesekali, dipercaya bahwa pendidik dapat mengatasi masalah yang mereka hadapi yang diidentifikasi dengan siklus pembelajaran di sekolah atau masalah perluasan keterampilan dan kemajuan profesinya.

2. Seminar.

Kerjasama para pendidik dalam kursus dan pelatihan distribusi logis juga dapat menjadi model untuk peningkatan tanpa henti dalam menunjukkan panggilan dalam mengembangkan kemampuan pendidik. Melalui tindakan ini, ini 
memberikan kesempatan kepada pendidik untuk berinteraksi secara deduktif dengan mitra dalam pemanggilan mereka sehubungan dengan masalah terbaru dengan tujuan akhir untuk meningkatkan sifat pelatihan.

3. Workshop.

Lokakarya diarahkan untuk memberikan barang-barang yang berharga untuk menguasai, mengembangkan kemampuan dan menciptakan panggilan. Workshop yang dapat dilakukan misalnya dalam latihan menyusun KTSP, menganalisis kurikulum, membuat jadwal, menyusun rencana latihan, dan lain-lain.

4. Penelitian.

Eksplorasi dapat diselesaikan oleh guru dalam berbagai jenis penelitian aktivitas wali kelas, penelitian percobaan atau jenis yang berbeda untuk meningkatkan sifat pembelajaran.

5. Penulisan buku/bahan ajar.

Bahan ajar yang telah disusun oleh pengajar misalnya sebagai bacaan mata kuliah, buku mata kuliah atau buku di bidang pelatihan.

6. Pembuatan media pembelajaran.

Media pembelajaran yang telah dibuat oleh pendidik dapat berupa bantuan pertunjukan, misalnya alat praktikum dasar, serta materi pertunjukan elektronik (kegiatan pembelajaran).

7. Pembuatan karya teknologi/karya seni. Karya kreatif yang dibuat oleh pendidik dapat menjadi karya yang inovatif sehingga bermanfaat bagi masyarakat dan / atau pelatihan dan mahakarya yang memiliki kualitas gaya yang dipersepsikan oleh masyarakat. (Arifin, 2006).

Pengembangan profesionalisme yang berkesinambungan dapat dibuat berdasarkan profil pelaksanaan pendidik sebagai tanda hasil evaluasi pelaksanaan kinerja pendidik. Dalam hal konsekuensi evaluasi pelaksanaan instruktur masih berada di bawah norma kompetensi yang telah ditetapkan sebelumnya atau pelaksanaannya rendah, maka perlu seorang pendidik untuk mengikuti program yang dapat disusun sebagai pelatihan untuk mencapai keterampilan yang memenuhi pedoman yang diperlukan.

Dalam Permenneg PAN dan RB Nomor 16 Tahun 2009, Kemajuan pengembangan profesionalitas pendidik yang berkesinambungan dianggap sebagai salah satu komponen fundamental yang akan diberikan fokus kredit untuk peningkatan karir pendidik dan bahkan peningkatan pangkat/jabatan fungsional guru, terlepas dari latihan/pembinaan dan/ atau tugas tambahan lainnya yang berkaitan dengan sekolah/madrasah kerja. Latihan peningkatan pengembangan profesionalitas pendidik yang gigih juga diharapkan dapat membuat pendidik yang sangat profesional, yang memiliki informasi luas, tetapi juga memiliki karakter dewasa. Dengan karakter yang prima dan dominasi ilmu pengetahuan dan inovasi yang kokoh, pendidik dituntut memiliki bakat dalam membangun minat dan kemampuan siswa sesuai dengan bidangnya.

\section{Kelemahan Kebijakan Pengembangan Profesionalisme Guru}

Berdasarkan Sebuah UndangUndang Nomor 14 Tahun 2005 tentang Guru, Peraturan Pemerintah nomor 74 tahun 2008 tentang Guru, Peraturan Menteri Pendayagunaan Aparatur Negara dan Reformasi Birokrasi Nomor 16 tahun 2009 tentang Jabatan Fungsional Guru dan Angka Kreditnya dan peraturan pelaksanaan lainnya, kebijakan pengembangan profesionalisme berkelanjutan wajib dilakukan guna mewujudkan guru profesional dan sebagai suatu sistem pembinaan yang dikaitkan dengan sebuah perolehan angka kredit jabatan fungsional. Perolehan angka kredit ini jika telah memenuhi nilai yang dipersyaratkan digunakan untuk menyusun DUPAK guna memperoleh penghargaan kenaikan pangkat dan golongan setingkat lebih tinggi, hal ini sebagaimana tertuang dalam pasal 48 ayat (1) Peraturan Pemerintah Nomor 74 Tahun 2008 tentang Guru, menyebutkan bahwa Pengembangan dan peningkatan kompetensi Guru dilakukan melalui sistem pembinaan serta pengembangan keprofesian Guru berkelanjutan yang 
menyunting karya ilmiah, membuat rancangan dan karya teknologi yang dipatenkan, dan membuat rancangan karya seni monumental/pertunjukkan. Kegiatan bersifat penelitian ini mendapatkan perhatian yang sangat besar dari Ditjen Pendidikan Islam dengan memberikan bantuan dana (grant / award) merupakanprogram penelitian dan publikasi ilmiah. Bantuan dana dan penghargaan ini dapat meliputi penelitian kompetitif kolektif, penelitian individual, pemberian award hasil penelitian terbaik bidang mata kuliah, kemudian sebuah program yang bernama yakni PAR pemberdayaan madrasah atau pesantren masjid serta masyarakat, dan program award disertasi/tesis/skripsi terbaik.

Ketiga, bidang pengabdian kepada masyarakat. Pengabdian pada masyarakat adalah tindakan yang menghubungkan konsekuensi pemeriksaan dan penguasaan berbagai disiplin ilmu yang berbeda di bidang pendidikan dengan peningkatan sifat pengajaran dan kemajuan eksplorasi, meskipun mendukung kemajuan dalam berbagai tingkat lapisan masyarakat. Bahkan Kegiatan pengabdian masyarakat menurut Keputusan Bersama Mendikbud dan Kepala BKN Tahun 1999 dapat mencakup: menduduki jabatan pimpinan pada lembaga pemerintahan yang harus dibebaskan dari jabatan organiknya, melaksanakan pengembangan hasil pendidikan dan penelitian yang bermanfaat bagi masyarakat, memberikan latihan dan penyuluhan pada masyarakat, memberikan layanan masyarakat / kegiatan lain yang menunjang tugas umum pemerintahan dan pembangunan.

Dalam rangka untuk pelaksanaan tugas dan kewajibannya, seorang dosen dituntut untuk dapat memiliki sejumlah kompetensi atau kemampuan dalam melaksnakan tugas pekerjaan yang dibebankan kepadanya. Menurut Peraturan Pemerintah Nomor 19 Tahun 2005 tentang Standar Nasional Pendidikan Pasal 28 ayat 3 bahwa kompetensi yang harus dimiliki oleh seorang pendidik (dosen) mencakup kompetensi pedagogik, kepribadian, professional, dan sosial.
Kemampuan mengajar adalah kemampuan untuk mengawasi siswa, yang meliputi mendapatkan siswa, merencanakan dan melaksanakan pembelajaran, dan menciptakan siswa dengan tujuan agar mereka dapat menyelesaikan berbagai kemungkinan mereka. Kebugaran karakter merupakan kapasitas karakter yang mantap, mantap, berkembang, lihai dan terhormat, menjadi teladan yang baik bagi siswa, dan memiliki karakter terhormat. Kemudian, proficient fitness adalah kemampuan untuk menguasai materi pembelajaran secara luas dan mendalam yang memungkinkan mereka untuk mengontrol siswa untuk memenuhi pedoman kompetensi yang telah ditetapkan. Sementara itu, kemampuan sosial adalah kapasitas guru sebagai komponen masyarakat untuk menyampaikan dan bergaul secara memadai dengan siswa, instruktur individu, staf pengajar, wali dan jaringan yang melingkupinya.

Dengan mengasah berbagai keterampilan, dipercaya akan tercipta guru yang berkualitas. Kualitas istilah juga dapat diartikan sebagai campuran sifat produk yang menunjukkan kapasitasnya untuk mengatasi masalah klien, baik secara sah atau sebagai implikasinya. (G.S. Lasut, 1996) Ada kewajaran atau keterkaitan antara hasil tugas pembicara dengan kebutuhan siswa dan jaringan yang mencakup (mitra).

\section{F. Peningkatan Kinerja Dosen}

Performa atau performance merupakan aktivitas seseorang dalam menjalankan tugas pokok yang diberikan kepadanya. (GS Lasut, 1996) Setiap orang yang mempunyai jabatan atau pekerjaan dalam pola tertentu selalu berkaitan dengan sejumlah tugas dan tanggung jawab yang harus dijalankan dan dijalankan. lengkap dan menyeluruh. (John Whitmore, 1997) Dengan demikian, penampilan kinerja seseorang merupakan hasil dari suatu pekerjaan atau tugas yang dilaksanakan dalam kurun waktu tertentu sesuai dengan profesinya dan pembahasan mengenai kinerja atau uraian tugas dari individu yang bersangkutan.

Dengan kata lain, bahwa kualitas kinerja dosen dapat dilihat dari pelaksanaan tugas dan tanggung jawabnya 
sebagai dosen, baik dalam bidang pendidikan dan pembelajaran, penelitian, maupun pengabdian pada masyarakat. Studi Ace Suryani yang ditulis oleh Rahman Assegaf dalam Artikel Swara Cendekia No. 5 (2005) menyebutkan bahwa kualitas kinerja dosen dapat dianalisis dari lima indikator, yaitu :

1. Kemampuan profesional (Professional Capacity) sebagaimana dapat terukur dengan ijasah, jenjang pendidikan, jabatan, golongan, dan pelatihan;

2. Upaya profesional (professional effort) sebagaimana terukur dari kegiatan mengajar, pengabdian dan penelitian;

3. Waktu yang digunakan untuk kegiatan profesional (teachers time) sebagaimana terukur dari masa jabatan, pengalaman mengajar, dan lainnya;

4. Kesesuaian antara keahlian serta pekerjaannya (link and match)sebagaimana terukur dari mata pelajaran yang diampu;

5. Tingkat kesejahteraan (Prosperiousity) sebagaimana dapat terukur dari upah, honor dan pengahsilan rutin lainnya.

Dalam kaitannya dengan menghadapi tantangan PTKIN ke depan, baik tantangan globalisasi maupun penciptaan manusia yang unggul, maka menurut Abdul Ghofir pada Artikel Swara Cendekia No. 3 bahwa tenaga pengajar yang berkualitas, yakni mampu menghadapi tantangan di masa depan dapat dilihat dari beberapa indikator, yaitu

1. Mempunyai landasan moral yang kokoh untuk berjihad dan mengemban amanah;

2. Berkemampuan mengembangkan jaringan kerjasama silaturahim;

3. Mempunyai team work begitu kompak;

4. Mencintai kualitas yang tinggi;

5. Produktif dalam menghasilkan karya keilmuan;

6. Mempunyai sikap dedikasi dan disiplin dalam melakukan pekerjaan;

7. Jujur dalam setiap aktivitas kehidupan;

8. Inovatif dalam melihat persoalan kekinian yang kurang relevan;
9. Tekun untuk menjalankan tugas dan kewajiban serta ulet dalam menghadapi realitas kehidupan.

Persoalan kualitas kenerja dosen dapat dikaji dan diteliti dari berbagai sudut pandang dan ukuran. Salah satu Kriteria yang dapat dipergunakan untuk melihat kualitas kinerja dosen adalah kembali pada bidang tugas dosen itu sendiri, yaitu melaksnakan Tri Dharma Perguruan Tinggi yang mencakup pendidikan, penelitian dan pengabdian pada masyarakat. Dalam kaitan ini, Sanusi Uwes mengembangkan kualitas kinerja dosen menjadi kualitas tugas pendidikan dan pembelajaran, mutu tugas penelitian, mutu tugas pengabdian pada masyarakat, mutu tugas pembimbingan, dan mutu tugas pelaksanaan administrasi.

Dalam kaitannya dengan pembinaan kualitas kinerja dosen, Ditjen Kelembagaan Islam merumuskan kebijakan yaitu meningkatkan kualitas akademik (dosen) melalui lain : 1) memprioritaskan untuk peningkatan kualitas dosen dengan melalui pendidikan, workshop, kursus serta pelatihan; 2) menggalakkan dalam karya tulis dosen; 3) memacu kreativitas serta produktivitas dosen berdasarkan kode etik profesi dosen; 4) kelanjutan jenjang studi strata 2 dan strata 3 secara regular; 5) ada keseimbangan antara hak dan kewajiban dosen termasuk tingkat kesejahteraan dosen harus diperhatikan.

Dengan kebijakan tersebut diharapkan dapat terwujud sosok dosen yang berkualitas yakni mampu melaksanakan tugas dan tanggung jawabnya secara optimal. Sosok idealitas dosen yang diharapkan adalah dosen yang mempunyai cirri-ciri sebagai berikut :

1. Selalu menunjukkan perilaku muslim, bertakwa pada Allah yang bangga dengan jati diri sebagai dosendan menghindari sikap rendah diri.

2. Menguasai secara mendalam bidang ilmu yang menjadi keahliannya yang mempu mengaktualisasikan dalam kehidupan modern dan selalu dapat berorientasi ke depan. 
3. Memiliki wawasan keilmuan serta intelektualisme yang luas dan mendalam, profesionalisme yang memadai serta metodologi yang tepat.

4. Menunjukkan dan memiliki perilaku yang disiplin, tekun, tanggung jawab, kritis, inovatif, dinamis, terbuka, menghargai sebuah pendapat orang lain, produktif, dan berakhlak mulia mudah beranggapan bahwa kerja adalah ibadah.

5. Berjiwa dan berlaku sebagai pendidik dan pembimbing yang jujur, amanah, ramah, komunikatif dan menaruh perhatian pada kesuksesan para mahasiswanya.

6. Berorientasi pada masa depan dan sadar untuk dapat meningkatkan ilmu serta kualitas pribadi, menjunjung tinggi pada kode etik dosen dan mematuhi semua ketentuan tentang kewajiban dosen.

7. Menghindari korupsi, kolusi dan nepotisme.

8. Menjunjung tinggi ukhuwah,serta kebersamaan, bijak, penuh dedikasi dan ibadah serta mampu menjadikan dirinya sebagai salah contoh yang baik bagi mahasiswanya dan memberikan kontribusi positif bagi masyarakat dan lingkungannya.

Dalam upaya mewujudkan kualitas kinerja dosen sebagaimana yang diharapkan oleh semua pihak, maka sudah saatnya lembaga pendidikan tinggi yang bersangkutan dan pihak terkait lainnya membangun suatu sistem pembinaan dosen (supervisi akademik) yang lebih efektif dan produktif. Di samping itu, selama ini realitas yang terjadi menunjukkan bahwa dengan anggapan dosen mempunyai otoritas penuh terhadap bidang tugasnya sehingga seakan-akan kurang diperlukan adanya control dari pihak lain. Hal ini juga dikarenakan belum adanya sistem dan mekanisme control dan pembinaan yang baik terhadap kinerja dosen di sebuah pendidikan tinggi. Padahal sebuah sistem pembinaan (supervisi akademik) bagi dosen merupakan alat sarana dan bagian dari upaya untuk meningkatkan kualitas serta kinerja para dosennya. Dengan adanya peningkatan kualitas dosen diharapkan akan dapat pula untuk meningkatkan kualitas proses perkuliahan dan output pendidikan.

Pembinaan para dosen sebenarnya merupakan sebuah proses yang dimulai dari tahap pengadaan dosen baru, masa bertugas hingga saat penarikan/pensiun. Hal ini erat kaitannya dengan sistem pengembangan atau pembaruan terhadap sumber daya manusia dan kebijakan yang telah digunakan oleh lembaga pendidikan yang bersangkutan. Pengadaan dosen baru terkait dengan kebutuhan riil ke depan dan dilakukan secara obyektif sesuai dengan ketentuan yang berlaku. Sedangkan masa bertugas, maka perlu adanya pembinaan dan dapat dikembangkan sesuai kemampuan bidang ilmu serta visi dan misi lembaga yang bersangkutan. Dalam masa pengembangan ini dapat ditempuh beberapa cara seperti pelatihan di tempat kerja (on the job training), program magang, dan pendidikan khusus.

Di samping itu, perlu diupayakan berbagai kegiatan yang menunjang lainnya untuk meningkatkan kemampuan profesionismenya. Kegiatan tersebut antara lain dengan melalui seminar, rapat kerja, kepanitiaan, studi banding, lomba karya tulis ilmiah, penghargaan atas karya ilmiah terbaik, pemilihan dosen terbaik, dan lain sebagainya. Pada masa penarikan / pensiun, perlu juga dipertimbangkan tentang kontribusi mereka selanjutnya seperti dengan memberikan perpanjangan masa kerja, atau dengan memberdayakan mereka sesuai dengan kemampuan dan profesinya.

\section{KESIMPULAN}

Perlu ada persyaratan untuk strategi pengembangan profesionalisme bagi guru, yang bermaksud untuk menciptakan dan memperluas kemampuan dan batasan setiap orang untuk pendidik sesuai dengan mata pelajaran khusus mereka. Ini harus dimungkinkan melalui pengajaran dan persiapan dalam sebuah bentuk in-house, program magang, atau antara asosiasi sekolah, langkah-langkah pembelajaran pemisahan, persiapan berlapis dan 
persiapan yang tidak umum, seperti kursus singkat, pelatihan interior oleh sekolah, dan instruksi lebih lanjut. Terlebih lagi, latihan yang dilakukan di luar lingkup pengajaran dan penyiapan meliputi perbincangan isuisu instruktif, kursus, lokakarya, penelitian, penyusunan buku / materi pertunjukan, pembuatan media pembelajaran, dan pembuatan inovasi/karya kreatif. Kebijakan untuk pengembangan profesionalisme bagi guru telah diatur dalam Peraturan Pemerintah Nomor 74 Tahun 2008 tentang Guru, Peraturan Menteri Pendayagunaan Aparatur Negara dan Reformasi Birokrasi Nomor 16 tahun 2009 tentang Jabatan Fungsional Guru dan Angka Kreditnya. Namun, juga kelemahan dalam kebijakan tersebut yaitu harus adanya sanksi guru yang tidak melaksanakan pengembangan profesionalisme belum diatur secara tegas mapun tertulis.

Di dalam penyelenggaraan pendidikan di lembaga pendidikan tinggi, dosen mempunyai suatu kedudukan yang sangat penting dan strategis dalam kerangka pencapaian tujuan pendidikan yang ditetapkan. Dosen mempunyai otoritas yang cukup besar dalam mengelola pendidikan dan perkuliahan, mulai dari penyusunan rencana perkuliahan, pelaksanaan, dan evaluasi serta tindak lanjutnya. Di samping tugas pada bidang pendidikan dan pembelajaran, dosen juga mempunyai tugas lainnya yaitu melaksanakan kegiatan penelitian, dan kegiatan pengabdian kepada masyarakat.

Untuk melaksanakan tugas dan tanggung jawabnya tersebut, dosen dituntut untuk mempunyai kemampuan atau kompetensi yang memadai, baik kompetensi personal, kompetensi sosial, kompetensi kepribadian serta sebuah kompetensi professional. Dengan kompetensi tersebut diharapkan dosen mampu mengantarkan para mahasiswanya menuju pintu gerbang sebagaimana yang diharapkan, di samping turut menentukan citra dan kualitas lembaga tempat mereka bekerja.

Pelaksanaan tugas dan tanggung jawab dosen tersebut senantiasa perlu dikontrol dan dikembangkan sedemikian rupa sehingga lebih optimal dan relevan dengan kebutuhan yang ada. Proses pengembangan dan pembinaan kemampuan

Dosen dalam melaksanakan tugasnya selama ini nampaknya belum mencapai kondisi yang diharapkan sehinga perlu adanya kajian dan penelitian yang intensif dan komprehensif dengan berbagai pendekatan yang relevan

\section{DAFTAR PUSTAKA}

Arifin. (2006). Profesionalisme Guru: Analisis Wacana Reformasi Pendidikan dalam Era Globalisasi. Malang: Simposium Nasional Pendidikan di Universitas Muhammadiyah.

G.S, Lasut. (1996). Sistem Analisis Interaksi Sebagai Instrumen Pengembangan Kompetensi

Profesional Pengawas Pendidikan. Manado: IKIP.

Hamalik, Oemar. (2002). Psikologi Belajar dan Mengajar. Bandung: Sinar Baru.

Islamy, Irfan. (2002). Prinsip-Prinsip Perumusan Kebijaksanaan Negara. Jakarta: Bumi Aksara.

Kebijakan Tahun (2004). Peningkatan Kualitas Akademik dan Administrasi PTAIN. Jakarta: Ditjen Bagais, 2004.

Kebijakan Pengembangan Profesi Guru Badan PSDMPK-PMP Kementerian Pendidikan Dan Kebudayaan, (2012).

Kepmen Pendidikan Nasional No. 36/D/O/2001 tentang Petunjuk Teknis Pelaksanaan Penilaian Angka Kredit Jabatan Dosen

Keputusan Bersama Mendikbud dan Kepala BKN Tahun 1999. 
Mulyasa, E. (2008). Standar Kompetensi dan Sertifikasi Guru. Bandung: Remaja Rosdakarya.

Nugroho D, Riant. (2006). Kebijakan Publik Untuk Negara-Negara Berkembang. Jakarta:PT. Elex Media Komputindo.

Peraturan Pemerintah Nomor 19 Tahun 2005 tentang Standar Nasional Pendidikan Pasal 28 ayat 3

Sagala, Syaiful. (2009). Konsep dan Makna Pembelajaran. Bandung : Cv. Alfabeta.

Sanusi, Uwes. (2003). Manajemen Pengembangan Mutu Dosen. Jakarta: Penerbit Logos Wacana Ilmu.

Studi Ace Suryani yang ditulis oleh Rahman Assegaf dalam Artikel Swara Cendekia No. 5 Th. I (2005:1)

Syaiful, Sagala. (2000). Administrasi Pendidikan Kontemporer. Bandung: CV. Alfabeta,

Tampubolon, Daulat P. (2001). Perguruan Tinggi Bermutu: Paradigma Baru Manajemen Pendidikan Tinggi Menghadapi Tantangan Abad 21. Jakarta: PT. Gramedia Pustaka Utama.

Undang-Undang RI Nomor 14 Tahun 2005 Tentang Guru dan Dosen Pasal $1 \mathrm{~d}$.

Wahab, Solichin Abdul. (2011). Pengantar Analisis Kebijakan Publik. Malang: UMM Press.

Whitmore, John. (1997). Coaching for Performance: Seni Mengarahkan untuk Mendongkrak Kinerja. Jakarta: Gramedia. 